Volume V, No.2 Desember 2015/1436 H

\title{
KONSEP SISTEM PENGELOLAN ZAKAT DI INDONESIA PENGENTAS KEMISKINAN PENDEKATAN SEJARAH
}

\author{
Muhammad Ngasifudin ${ }^{1}$ \\ Prodi Ekonomi Syariah STIA Alma Ata Yogyakarta \\ Email: ngaciefudien@gmail.com
}

\begin{abstract}
Zakat is the primary means of communication between man and another man in bermasyarat sake compose a harmonious and humane life. The role of Zakat, both property and tithes would be more visible subtle and implemented together with other instrumental value that is usury. Obligation of alms giving firm and absolute top of every Muslim, premises object property that is property and income that have fulfilled the obligation of zakat and charity penunian-value embodied wisdom and universal values that benefit the community life and poverty pengentas
\end{abstract}

Keywords: Zakat, Equity, Poverty

\section{PENDAHULUAN}

Salahsatucara untukmenekanangkakemiskinan,orangIslamingin memanfaatkandanazakat.UsahaIslamdalammenanggulangiproblem kemiskina nini,bukanlahsuatuhalyangmengada-ada,temporer,setengahsetengahbahkanha nyamencariperhatian.Penguranganangkakemiskinan, bagi Islam, justru menjadi asas yang khas dan sendi-sendi yang kokoh. Hal ini dibuktikan dengan zakat yang telah dijadikan oleh Allah s.w.t sebagai sumber jaminan hak-hak orang-orang fakir dan miskin itu sebagai bagian dari salah satu rukun Islam (Qardawy. 1999)

Dalam sejarah perkembangan Islam, zakat menjadi sumber penerirnaan negara dan berperan sangat penting sebagai sarana penanggulangan kemiskinan kemudian syiar agama Islam, pengembangan dunia pendidikan dan kebudayaan, pengembangan ilmu pengetahuan, pernbangunan infrastruktur, pembiayaan dan pembangunan angkatan perang serta keamanan dan penyediaan layanan kesejahteraan sosial lainnya. Filosof zakat dalam agama Islam adalah salah satu alternatif pendanaan bagi kemaslahatan umat yang perlu diberdayakan secara optimal untuk memperbaikikesejahteraan dan perbaikan ekonomi umat. Oleh karenaitu setiap muslim yang rnemiliki harta dan telah memenuh syarat-syarat tertentu dan ketentuan ajaran agama Islam diwajibkan mengeluarkan zakat yang diberikan kepada mereka yang berhak khususnya fakir miskin. mayoritas penduduknya beragama Islam, adalah negarayang merniliki potensi zakat sangat besar jumlahnya.Potensi ini adalah merupakan sumber pendanaan yangsangat potensial dan akan 
menjadi sebuah kekuatan pemberdayaan ekonomi, pemerataan pendapatan danbahkan lebih jauh lagi dapat meningkatkan perekonornian bangsa. Potensi ini sebelumnya hanya dikelola oleh individu-individu, secara tradisional dan bersifatkonsumtif,sehingga pemanfaatannya belum optimal. (Kementrian Agama Republik Indonesia, 2011)

Berbagai program pengentasan kemiskinan telah diupayakan dan digagas, baik oleh pemerintah maupun organisasi di luar pemerintah (sektor swasta, NGO, donor agency). Bahkan organisasi dunia seperti PBB telah mendorong negara-negara di dunia untuk memerangi musuh kemiskinan melalui berbagai forum. Diantara hasilnya ialah telah dikeluarkannya Millennium Development Goals (MDGs) sebagai indikator untuk mengukur keberhasilan dalam memerangi kemiskinan (Ma'arif, 2007)

Orang Islam sangat meyakini dan mengamini bahwa zakat adalah pilar ketaatan seorang muslim kepada Tuhan-Nya, Semakin hari semikin makin besar pula harapan umat Islam Indonesia agar melaksanakan pemungutan Zakat dapat di lakukan dengan sebaik-baiknya, Hal ini di ungkapkan Dalam Rakernas Baznas Mengenai penghimpunan BAZNAS 2016 mulai dari tingkat kabupaten/kota, provinsi hingga pusat, diharapkan mencapai Rp 5,27 triliun. Target yang ditetapkan diupayakan agar dapat terus mendekati potensi zakat Tanah Air yang jumlahnya signifikan untuk digunakan sebagai salah satu instrumen peningkatan kesejahteraan umat. (BAZNAS, 2015). Islam, sekali lagidengan komitemen sosialnya yang begitu eksplisit, telah di reduksi menjadi agama yang hanya berurusan dengan peri kehidupan yang bersekala personal dan bersifat penuh ritual, sehingga untuk dimensi kehidupan induvidual utamannya, barangkali islam masih membersitkan pengaruhnya, akan tetapi untuk dimensi kehidupan sosialnya pengaruh itu hampir-hampir tidak terasa, masuk dalam tatanan masyarakat fedolistis, umat islam ikut bersifat feodal, masuk tatanan masyarakat borjouis kapitalis juga ikut berperilaku seperti itu.

Upaya untuk menegakan kesalihan sosial melalui konsep zakat ini sudah banyak dilaksanakan orang, dan akan terus saja dilaksanakan dikalangan masyarakat kita, terutama menjelang lebaran puasa. Berbagai bentuk kepanitiaan zakat muncul dimana-dimana, umumnya bersekala lokal, baik berkaitan dengan kepengurusan masjid, dengan kepengurusan ormas islam, dengan lembaga pendidikan, majelis taklim dan sebagainya, sementara kepanitiaan musiman itu digalakan, pemerintah sendirimelalui inisiatif birokrat muslim yang berperan di dalamnya, juga telah mencanangkan gerakan pengelolaan zakat melalui aparat birokrasinya, Apabila padamulanya gerakan ini merupakan inisiatif lokal dari aparat pemerintah daerah dengan Bazi-nya maka sejak awal tahun 1991 ini dicoba ditingaktkan menjadi suatu gerakan nasional yang didukung oleh SKB dua menteri, Menteri Agama dan Menteri dalam Negeri(Mas'udi, 1991)

Tulisan ini merupakan usaha untuk mencoba memperjelas bagaimana Islam menjaga keseimbangan antara ketimpangan sosial melalui pengelolan zakat sebagai bentuk tatanan sosial "hablum mina nas"

\section{Sejarah pengelolan zakat pada masa Nabi Muhammad}

Peradaban Islam adalah cermin kultural dari kalangan elit yang dibangun dengan kekuatan-kekuatan ekonomi dan perubahan sosial. Peradaban Islam terbentuk berkat penaklukan bangsa Arab selama delapan tahun

\section{Muhammad Ngasifudin}

JURNAL EKONOMI SYARIAH INDONESIA, Volume V, No.2 Desember 2015 
masa pertempuran. Nabi Muhammad saw. berusaha meraih kekuasaan atas suku-suku dalam rangka menundukkan Mekah. Sejumlah utusan dan duta dikirim ke seluruh penjuru Arabia. Sementara suku-suku bangkit untuk menyampaikan kesetiaan, membayar zakat dan pajak, sebagai simbol keanggotaan dalam komunitas muslim dan simbol menerima Muhammad sebagai Nabi dan Utusan Allah swt. (Lapidus, 2000)

Ulama berpendapat bahwa adanya porsi zakat yang diperuntukkan bagi Amil merupakan suatu indikasi bahwa zakat sewajarnya dikelola oleh lembagakhusus zakat atau yang disebut dengan Amil bukan oleh individu muzakki sendiri. Rasulullah SAW pernah mempekerjakan seorang pemuda dari Suku Asad,yang bernama Ibnu Lutaibah, untuk mengurus urusan zakat Bani Sulaim. Pernah pula mengutus Ali bin Abi Thalib ke Yaman untuk menjadi amil zakat. Muaz bin Jabal pemah diutus Rasulullah SAW pergi ke Yaman, disamping bertugas sebagai da'i, juga mempunyai tugas menjadi amil zakat. Menurut Yusuf Al-Qardawi, Nabi SAW telah mengutus lebih dari 25 Amil ke seluruh pelosok Negara dengan memberi perintah untuk pengumpuJan sekaJigus mendistribusikan zakat sampai habis sebelum kembali ke madinah (Kementrian Agama Republik Indonesia, 2013).

Pembukuan zakat juga dipisahkan dari pendapatan Negara lainnya, pencatatan zakat juga dibedakan antara pemasukan dan pengeluaran, di mana keduanya harus terinei dengan jelas, meskipun tanggal penerimaan dan pengeluaran sarna. Selain itu, Nabi SAW berpesan pada para amil agar berlaku adil dan ramah, sehingga tidak mengambil lebih dari apa yang sudahditetapkan dan tidak berlaku kasar baik pada muzakki maupun rnustahiq. Secara garis besar dapat dikatakan bahwa pada zaman Nabi SAW pengelolaan zakat bersifat terpusat dan ditangani secara terpusat, namun demikian pengelolaan zakat pada saat itu secara institusional dapat dianggap sederhana dan masih terbatas dengan sifatnya yang teralokasi dan sementara, di rnanajumlah zakat yang terdistribusi akan tergantung pada jumlah zakat yang terkumpul pada daerah atau kawasan tertentu, dan uang zakat yang terkumpul langsung didistribusikan kepada para mustahiq tanpa sisa (Kementrian Agama Republik Indonesia, 2013).

Dalam bidang pengelolaan zakat Nabi Muhammad saw. memberikan contoh dan petunjuk oprasionalnya. Manajemen operasional yang bersifat teknis tersebut dapat dilihat pada pembagian strukturamil zakat, yang terdiri dari: (1) Katabah, petugas yang mencatat para wajib zakat, (2)Hasabah, petugas yang menaksir, menghitung zakat, (3) Jubah, petugas yang menarik, mengambil zakat dari para muzakki, (4) Khazanah, petugas yang menghimpun dan memelihara harta, dan (5)Qasamah, petugas yang menyalurkan zakat pada mustahiq (orang yang berhak menerima zakat) (Nasution, 2006)

Dalam praktiknya, Nabi tidak membagi rata hasil zakat yang terkumpul kepada delapan kelompok tersebut. Nabi membagi sesuai kebutuhan. Maka konsekuensinya, ada salah satu kelompok yang tidak memperoleh zakat karena persediaan zakat di alokasikan kepada kelompok lain yang lebih membutuhkan. Dengan demikian, sistem distribusi zakat pada masa Rasulullah diatur secara proporsional dan kondisional disesuaikan dengan tingkat kebutuhan mustahiq zakat.

\section{Konsep Zakat pada Masa Sahabat}

Sistem

Pada masa Abu Bakar, selama dua tahun sejak wafat Rasulullah SAW, sebenarnya belum terjadi perubahan mendasar tentang kebijakan pengelolaan 
zakat dibandingkan dengan masa Rasulullah. Namun pada periode ini terjadi sebuah peristiwa penting yang menyangkut zakat, Setelah RasuLullah SAW wafat, banyak kabilahkabilah yang menolak untuk membayar zakat denganalasan bahwa zakat merupakan perjanjian antara mereka dan Nabi SAW, sehingga setelah beliau wafat maka kewajiban tersebut menjadi gugur. Abu Bakar yang menjadi khalifah pertama penerus Nabi SAW memutuskan untuk memerangi mereka yang rnenolak membayar zakat dan menganggap mereka sebagai orang murtad. Perang ini kemudian terkenal dengan sebutan Harbu Riddah atau perang melawan pemurtadan. Perang ini tercatat sebagai perang pertama di dunia yang dilakukan sebuah Negara demi membelahak kaum miskin atas orang kaya. (Kementrian Agama Republik Indonesia, 2013).

Setelahwafatnya Abu Bakar dan dengan perluasan wilayah Negara Islam yang mencakup dua kerajaan besar pada masa tersebut yaitu sebagian kerajaan Romawi (Syria, Palestina, dan Mesir) dan seluruh kerajaan Persia terrnasuk Irak, ditambah dengan melimpahnya kekayaan Negara pada masa khilafah,telah memicu adanya perubahan pada system pengelolaan zakat. Kedua faktor tersebut mengharuskan terjadinya institusionalisasi yang lebih tinggi dari system pengelolaan zakat. Perubahan ini tercerrninsecara jelas pada masa Khalifah Umar bin Khattab. Umar mencontoh sistem adrninistrasi yang diterapkan di Persia, di mana sistem administrasi pemerintahan dibagi menjadi delapan provinsi, yaitu Mekkah, Madinah, Syiria, Jazirah, Basrah, Kufah, Palestina dan Mesir. Umar kemudian mendirikan apa yang disebut dengan Al-Dawawin yang sarna fungsinya dengan Baitul Maal pada zaman Nabi SAW di mana ia merupakan sebuah badan audit Negara yang bertanggungjawab atas pembukuan pemasukan dan pengeluaran Negara. Al-Dawawin juga diperkirakan mencatat zakat yang didistribusikan kepada para mustahiq sesuai dengan kebutuhan masing-masing. Pen gembangan yang dilakukan Umar terhadap Baitul Maal merupakan kontribusi Umar kepada dunia Islam. Pada masa Umar pula system pemungutan zakat secara langsung oleh Negara, yang dimulai dengan pemerintahan Abdullah bin Masud di Kufah di mana porsi zakat dipotong dari pembayaran Negara. Meskipunhal ini pemah diterapkan pada Khalifah Abu Bakar, namun pada masa Umar proses pengurangan tersebut menjadi lebih tersistematis. (Kementrian Agama Republik Indonesia, 2013)

Pengelolaan zakat pada masa 'Usman dibagi menjadi dua macam: (1) Zakat al-amwal az-zahirah (harta benda yang tampak), seperti binatang ternak dan hasil bumi, dan (2) Zakat alamwal al-batiniyah (harta benda yang tidak tampak atau tersembunyi), seperti uang dan barang perniagaan. Zakat kategori pertama dikumpulkan oleh negara, sedangkan yang kedua diserahkan kepada masing-masing individu yang berkewajiban mengeluarkan zakatnya sendiri sebagai bentuk self assessment (Permono, 1995)

Periode 'Ali ibn Abi Talib ra. Situasi politik pada masa kepemimpinan Khalifah 'Ali ibn Abi Talib ra. berjalan tidak stabil, penuh peperangan dan pertumpahan darah. Akan tetapi, 'Ali ibn Abi Talib ra. tetap mencurahkan perhatiannya yang sangat serius dalam mengelola zakat.Ia melihat bahwa zakat merupakan urat nadi kehidupan bagi pemerintahan dan agama. Ketika 'Ali ibn Abi Talib ra. bertemu dengan orang-orang fakir miskin dan para pengemis buta yang beragama non-muslim (Nasrani), ia menyatakan biaya hidup mereka harus ditanggung oleh Baitul Mal. Khalifah 'Ali ibn Abi Talib ra. juga ikut terjun langsung dalam mendistribusikan zakat kepada para mustahiq(delapan golongan yang berhak menerima zakat). (Qodir, 1998)

\section{Muhammad \\ Ngasifudin}

222

JURNAL EKONOMI SYARIAH INDONESIA, Volume V, No.2 Desember 2015 


\section{Pengelolan Zakat Di indonesia}

\section{Masa kerajaan Islam}

Menurut cendekiawan muslim Indonesia Masdar F Mas'udi Zakat pada mulanya adalah "upeti" dalam bahasa Muhammad Rasullulah yang orab itu sesaji udihiyah, juga terdapat lembaga "upeti" atau apa saja orang menyebutnya. Islam datang bukan untuk membrangusnya atau membuat lembaga sejenis sebagai pesaing atau alternatifnya, Ia hanya ingin lembaga upeti yang telah membangkai dan membuat kesengsaraan orang banyak di mana-mana itu dapat ditrnasformasikan, bahkan bisa ditransubtansikan, justru untuk menegakan kesejahteraan orang banyak. Dalam perkembangannya, upeti secara nyata telah membuat yang miskin terus tenggelam dalam kemiskinannya, sementara yang kaya para pengusaha dan segenap kerabat serta kaki tanganya terus memumbung keatas mengikuti kecenderungan nafsu dan keinginannya, kini keadan harus di balik, dengan sepirirt "Zakat" lembaga upeti justru manjadi sarana yang efektif agar kekayaan dan fasilitas kehidupan bisa diatus sedemikian rupa, tidak hanya melingkar-melingkar di antra kelompok tertentu saja, dengan sepirit "Zakat" lembaga upeti yang semulanya menjadi sumber kezhaliman harus di transformasikan menjadi wahana keadilan. (Mas'ud, 1991)

"Zakat" sebagai konsep keagamaan, di satu pihak, dan "pajak" sebagai konsep keduniawian, di pihak lain, bukanlah hubungan dualisme yang dikotomis melainkan hubungankeesaan wujud yang dialektis. Zakat bukan sesuatu yang harus dipisahkan, diparalelkan, dan apalagi dipersaingkan dengan "pajak", melainkan justru merupakan sesuatu yang harus disatukan sebagaimana disatukannya roh dengan badan atau jiwa dengan raga. "Zakat" merasuk ke dalam "pajak" sebagai ruh dan jiwanya, sedangkan "pajak" memberi bentuk pada "zakat" sebagai badan atau raga bagi proses pengejewantahannya (Mas'ud, 1991)

Kerajaan berperan aktif dalam mengumpulkan pajak-pajak tersebut, dan kerajaan membentuk sebuahbadan yang ditangani oleh pejabat-pejabat kerajaan dengan tugas sebagai penarik pajak atau zakat. Pemungutan pajak ini dilakukan di pasar-pasar, muara-muara sungai yang dilintasi oleh perahuperahu dagang, dan terhadap orang-orang yang berkebun, berladang, atau orang yang menanam di hutan. Karena itulah, banyak sekali macam dan jenis pajak yang diberlakukan pada setiap sumber penghasilan dan penghidupan warganya. Kantor pembayaran pajak ini pada masa kekuasaan kerajaan Aceh berlangsung di masjid-masjid. Seorang imeumdan kadi (penghulu) ditunjuk untuk memimpin penyelenggaraan ritual-ritual keagamaan. Penghulu berperan besar dalam mengelola keuangan masjid yang bersumber melalui zakat, sedekah, hibah, maupun wakaf. (Azra, 2006)

\section{Masa Kolonialisme}

Ketika bangsa Indonesia sedang berjuang melawan penjajahan Barat dahulu, zakat berperan sebagai sumber dana bagi perjuangan kemerdekaan tersebut. Setelah mengetahui fungsi dan kegunaan zakat yang semacam

Konsep

Sistem itu, Pemerintah Hindia Belanda melemahkan sumber keuangan dan dana perjuangan rakyat dengan cara melarang semua pegawai pemerintah dan priyayi pribumi mengeluarkan zakat harta mereka. Kebijakan Pemerintah Hindia Belanda ini menjadi batu sandungan dan hambatan bagi terselenggaranya pelaksanaan zakat (Ali, 1988) 
Wacana keislaman pada masa penjajajan tidak bisa mengesarnpingkan nama Dr. C. Snouck Hurgronye yang merupakan Penaseha Urusan Pribumi dan Islam. Data rnengenai praktek filantropi Islam sebagin besar didapat tulisan dan surat-surat Snouck yang ditujukan kepada Gubemul Jenderal atau pejabat daerah (Bupati, Residen, Asisten Residen) di bawah Hindia Belanda. Dengan nasehat-nasehatnya, Sonuck adalah tokoh yang paling berpengaruh dalam memutuskan kebijakan kolonial terhadap bentuk pengelolaan kas masjid yang didapatkan melalui zakat dan biaya pemikahan serta Zakat.Dalam pelaksanaan ajaran agama Islam (termsuk zakat) diatur dalam Ordanantie Pemerintah Hindia Belanda. Nomor 6200 tanggal 28 Pebruari 1905. Dalam peraturan ini pemerintah tidak mencampuri masalah pengelolaan zakat dan menyerahkan sepenuhnya kepada umat Islam dan bentuk pelaksanaannya sesuai syari'ah Islam. Pemerintah Hindia Belanda mengedarkan larangan tegas tertanggal 18 Agustus 1866 nomor 216 untuk menghapus semua campur tangan pemerintah daerah atas pungutan sukarela keagamaan. (Kementrian Agama Republik Indonesia, 2013).

\title{
Masa Awal kemerdekaan
}

Pada awal kemerdekaan Indonesia, pengelolaan zakat tidak diatur pemerintah dan masih menjadi urusan masyarakat. Kemudian pada tahun 1951 barulah Kementerian Aagama mengeluarkan Surat Edaran Nomor : A/ VIV 17367 tanggal 8 Desember 1951 tentang Pelaksanaan Zakat Fitrah. Pada tahun 1964 Kementerian Agarna menyusun Rancangan Undang-undang tentang Pelaksanaan Zakat dan Rancangan Peraturan Pemerintah mengganti Undangundang tentang Pelaksanaan Pengurnpulan dan Pembagian Zakat serta Pembentukan Baitul Maal, tetapi kedua perangkat peraturan tersebut belum sempat diajukan kepada Dewan Perwakilan Rakyat maupun kepada Presiden. (Kementrian Agama Republik Indonesia, 2013)

Kendatipun Negara Republik Indoensia tidak didasarkan pada ajaran suatu agama, namun falsafah negara kita dan pasal Undang-undang dasar negara republik Indonesia memberikan kemungkina kepada pejabatpejabat negara untuk membantu pelaksanan pemungutan zakat dan pendaya gunaanya, perhatian pemerintah terhadap lembaga zakat ini secara kualitatif,mulai meningkat pada tahun 1986, pada tahun itu pemerintah mengeluarkan peraturan menteri Agama nomor 4 dan Nomor 5/1968, masing masing tentang pembentukan Badan Amil Zakat dan pembentukan Baitul Mal (Balai harta kekayaan) di tingkat pusat, propinsi dan Kabupten (Ali, 1988)

\section{Masa Orde baru}

Pada masa orde baru presiden suharto memberikan angin segar, menteri keuangan pada waktu itu, dalam jawabannya kepada menteri Agama menyatakan bahwa perturn zakat tidak perlu dituangkan dalam undangundang, cukup dengan peraturan menteri Agama saja, Dengan dipelopori oleh pemerintah Daerah DKI Jaya yang pada waktu itu dipimpin oleh Gubernur Ali Sadiki, berdirilah di Ibukota badan Amil Zakat, Infaq dan Shadaqah (Bazis) pada tahun 1968. Di berbagai tingakat propinsi setelahitu berdiri pula badan serupa yang dipelopori oleh pejabat atau unsurpemerintah setempat dengan dukungan para ulama dan pemimpin islam atau sebaliknya, dengan demikian terbentuklah Badan Amil Zakat yang bersifat semi pemerintah. Umumnya melalui surat keputusan gubernur. Kini dikenal Bazis atau Baz di Aceh (1975),

\author{
Muhammad \\ Ngasifudin \\ 224
}

JURNAL EKONOMI SYARIAH INDONESIA, Volume V, No.2 Desember 2015 
Sumatera Barat (1973), Sumatra Selatan lampung (1975), DKI Jaya (1968), Jawa Barat (1974), Kalimantan Selatan (1977), Kalimantan Timur (1972) Sulawesi utara, Sulawesi Selatan (1985) dan Nusa Tenggara Barat. (Ali,1988)

Perkembangan zakat pada masa Orde Baru ini tidak sama di setiap daerahnya. Sebagian masih pada tahapan konsep atau baru ada di tingkat kabupaten seperti Jawa Timur. Atau ada pula yang hanya dilakukan oleh Kanwil Agama setempat. Karena itulah, mekanisme penarikan dana oleh lembaga zakat ini bervariasi. Di Jawa Barat hanya terjadi pengumpulanzakat fitrah saja. Di DKI Jaya terjadi pengumpulan zakat, ditambah dengan infaq dan shadaqah. Dan di tempat-tempat lain masihmeniru pola pada masa awal penyebaran Islam, yakni menarik semua jenis harta yang wajib dizakati. (Rahardjo, 1987)

Pada tahun 1989 dikeluarkan Instruksi Menteri Agama Nomor 16 Tahun 1989 tentang Pembinaan Zakat, Infaq dan Shadaqah yang menugaskan sernua jajaran Departemen Agarna untuk membantu lembaga-lembaga keagamaan yang mengadakan pengelolaan zakat, infaq dan shadaqah agar menggunakan dana zakat untuk kegiatan pendidikan Islam dan lain-lain, Pada tahun 1991 telah dikeluarkan Keputusan Bersama Menteri Agama dan Menteri Dalam Negeri Nomor 29 dan 47 tentang Pembinaan Badan Amil Zakat Infaq dan Shadaqah. Dalam SKB tersebut dijelaskan bahwa pengelo1aan zakat dilakukan Badan Amil Zakat, Infaq dan Shadaqah yang disingkatBAZIS yang dibentuk di tingkat provinsi sampai tingkat desa/kelurahan. SKB tersebut ditindaklanjuti dengan Instruksi Menteri Agama Nornor 5 Tahun 1991 tentang Pedeman Pembinaan Teknis Badan Amil Zakat, Infaq dan Shadaqah. Instruksi ini ditujukan kepada jajaran Departemen Agama untuk membina secara teknis tugastugas BadanAmil Zakat, Infaq dan Shadaqah. Kemudian SKB tersebut juga ditindaklanjuti dengan Instruksi Menteri Dalam Negeri 7 Tahun 1998 tentang Pembinaan Umum Badan Amil Zakat, Infaq dan Shadaqah. Instruksi ini ditujukan kepada jajaran Departemen Dalam Negeri untuk membina secara umum tugas-tugas Badan Amil Zakat, Infaq dan Shadaqah. (Kementrian Agama Republik Indonesia, 2013)

\section{Masa Reformasi}

Terbentuknya Kabinet Reformasi memberikan peluang baru kepada umat Islam, yakni kesempatan emas untukkembali menggulirkan wacana RUU Pengelolaan Zakat yang sudah 50 tahun lebih diperjuangkan. Komisi VII DPR-RI yang bertugas membahas RUU tersebut. Penggodokan RUU memakan waktu yang sangat panjang, hal itu disebabkan perbedaan visi dan misi antara pemerintah dan anggota DPR. Satu pihak menyetujui apabila persoalan zakat diatur berdasarkan undang-undang. Sementara pihak lain tidak menyetujui dan lebih mendorong supaya pengaturan zakat diserahkan kepada masyarakat, Pada tahun 1999 Undang-undang Nomor 38 tahun 1999 tentang Pengelolaan Zakat dikeluarkan oleh pemerintah. Pemerintah bersama Dewan Perwakilan Rakyat (DPR) berusaha memajukan kesejahteraan sosial dan perekonomian bangsa (Fakhruddin, 2008)

Pendayagunaan zakat diperuntukkan khusus bagi mustahiq delapan

Konsep

Sistem

225 asnaf. Sesuai dengan penjelasan Undang-Undang Pengelolaan Zakat, mustahiq delapan asnaf ialah fakir, miskin, amil, muallaf, riqab, gharim, sabilillah dan ibnu sabi1 yang dalam aplikasinya dapat meliputi orang-orang yang paling tidak berdaya secara ekonomi, seperti ana,k yatim, orang jompo, penyandang 
eacat, orang yang menuntut ilmu, pondok pesantren, anak terlantar, orang yang terlilit utang, pengungsi yang terlantar dan korban bencana alam Pola penyaluran dan pendayagunaan zakat antaralain:

Distribusi dan pendayagunaan untuk delapan asnaf.

Mernprioritaskan asnaf faki'r miskin.

Untuk memenuhi keperluan pokok, seperti makan dan tempat tingga1.

Bantuan makanan luang dapat dilakukan berkala atau han besar Islam.

Untuk keperluan desa binaan bagi pengentasan kemiskinan.

Bantuan pendidikan berupa beasiswa.

Bantuan pemberdayaan ekonomi umat, dll.

Pendayagunaan infaq, shadaqah, hibah, wasiat, waris dan kafarat diutamakan untuk usaha yang produktif agar dapat meningkatkan kesejahteraan masyarakat urnum. Prosedumya ditetapkan sebagai berikut:

Melakukan studi kelayakan.

Menetapkan usaha produktif.

Melakukan bimbingan dan penyuluhan.

Melakukan pemantauan, pengendalian danpengawasan.

Mengadakan evaluasi.

Membuat laporan. (Kementrian Agama Republik Indonesia, 2013)

Pengelolaan Zakat Pasca Undang-Undang Nomor 23 Tahun 2011 tentang

Pengelolaan Zakat

Kelahiran Undang-undang Nomor 23 Tahun 2011 tentang Pengelolaan Zakat menjadi sejarah penting dalam sejarah pengelolaan zakat di Indonesia sebagai revisi UU pengelolaan zakat sebelumnya. Undangun dang ini menjadi tonggak kebangkitan pengelolaan zakat di Indonesia setelah sekian puluh tahun termarjinalkan dan titik balik terpenting dunia zakat nasional. Berdasarkan Undang-Undang Nomor 23 tahun 2011 bahwa pengelolaan zakat dilakukan Badan Arnil Zakat Nasional (BAZNAS) dan Lembaga Amil Zakat (LAZ). BadanArnil ZakatNasional (BAZNAS) adalah lembaga pengelola zakat yang dibentuk oleh pemerintah, dari tingkat nasional sampai kecamatan. Untuk tingkat nasional dibentuk BAZNAS, tingkat provinsi dibentuk BAZNAS Provinsi, tingkat kabupaten/kota dibentuk BAZNAS Kabupaten/ Kota dan tingkat kecamatan dibentuk BAZNAS Kecamatan. Organisasi BAZNAS di semua tingkatanbersifat koordinatif, konsutatif dan informatif.

Guna tercapainya tujuan yang lebih optimal dalam pengelolaan zakat untuk kesejahteraan umat, maka dalam Undang-Undang disebutkan bahwa Lembaga Pengelola Zakat tidak hanya mengelola zakat, tetapi juga mengelola infaq, shadaqah, hibah, wasiat, waris dan kafarat. Pendayagunaan zakat diperuntukkan khusus bagi mustahiq delapan asnaf. Sesuai dengan penjelasan Undang- Undang Pengelolaan Zakat, mustahiq delapan asnaf ialah fakir, miskin, amil, muallaf, riqab, gharim, sabilillah dan ibnu sabil yang dalam aplikasinya dapat meliputi orang-orang yang paling tidak berdaya secara ekonomi, seperti anak yatim, orang jompo, penyandang cacat, orang yang menuntut ilmu, pondok pesantren, anak terlantar, orang yang terlilit utang, pengungsi yang terlantar dan korban bencana ala (Kementrian Agama Republik Indonesia, 2013) 


\section{Analisa Masa Depan Pengelolan Zakat di Indonesia}

Dengan berpedoman kepada ayat suci al-Qur'an dan mencontoh teladan Rasulullah SAW maka amil sudah seharusnya menfungsikan tugas-tugasnya yang dinamis dan proaktif serta efektif dalam mengelola zakat Pola distribusi zakat secara produktif dapat mengambil skema qardul hasan atau mudharabah. Pola qardul hasan merupakan salah satu bentuk pinjarnan yang menetapkan tidak adanya tingkat pengembalian tertentu dari pokok pinjaman. Narnun jika si peminjam dana tersebut tidak mampu mengembalikan pinjaman pokok tersebut, si peminjam tersebut tidak dapat dituntut atas ketidakmampuannya mengembalikan pinjaman, karena pada dasarnya dana tersebut adalah hak mereka. Sementara distribusi zakat secara produktif dengan skema mudharabahberarti lembaga pengelola zakat membuat terobosan dengan bertindak sebagai investor yang menginvestasikan dana hasil pengumpulan zakat kepada mustahik sebagai peminjam dana dengan angsuran pinjaman dan tingkat pengembalian yang dibayarkan menu rut kesepakatan. Hasil keuntungan dari usaha tersebut dikembangkan dan diperluas bagi mustahik yang lain sehingga terdapat pemerataan bagi usaha produktif yangmenguntungkan. Pendistribusian zakat secara produktif perlu dilakukan dengan langkah-langkah yang tepat agar dapat rnencapai sasaran secara tepat guna. (Kementrian Agama Republik Indonesia, 2013)

\section{Bagan Retribusi Zakat Produktif}

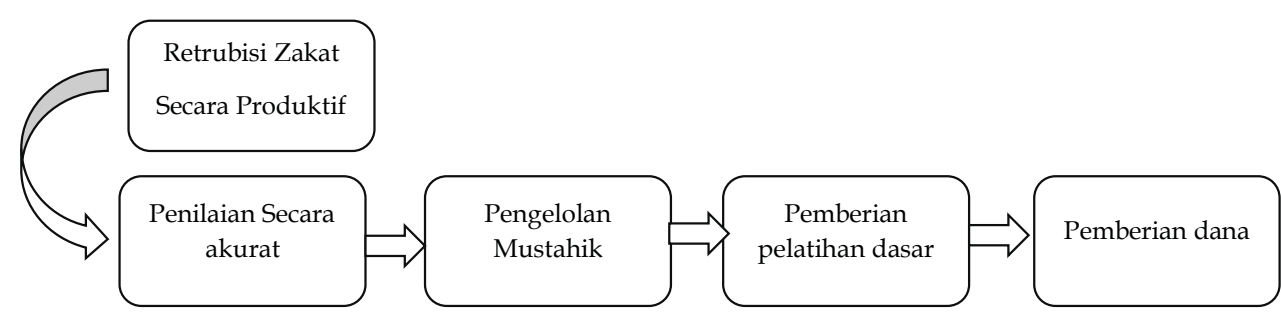

Menolong mereka meskipun sifatnya pribadi, akan tetapi mempunyai dampak sosial, karena masing-masing mempunyai hubungan erat, sebab secara pasti antara pribadi dengan masyarakat akan saling berpengaruh, bahkan masyarakat itu tidak lain merupakan kumpulan pribadi-pribadi, segala sesuatu yang memperkuat pribadi mengembangakan cita-citannya dan kemampuan material serta spiritualnya, dengan tidak diragukan lagi akan memperkuat dan mempertinggi masyarakatnya. Sebaliknya segala sesuatu yang mengkokohkan masyarakat dengan sifatnya yang umum akan berakibat kepada anggotanya, baik disadari maupun tidak, maka tidak aneh dengan menyibukan para pengangguran, menolong orang-orang yang lemah dan membutuhkan, zakat adalah salah satu bagian dari aturan jaminan sosial dalam islam, dimana aturan jaminan sosial ini tidak dikenal oleh barat, kecuali dalam lingkup yang sempit yaitu jaminan pekerjaan dengan menolong klomppok yang lemah dan fakir. Islam memperkanalkan aturan ini dalam lingkup yang lebih dalam dan luas, yang mencakup segi kehidupan Konsep material dan spiritual, seperti jaminan akhlak, pendidikan, ekonomi, jaminan Sistem kemanusiaan, jaminan kebudayaan, dan yang terakhir adalah jaminan sosial Islam menegakan prinsip dasar sebagaimana diisyaratkan oleh ayat mustahiq zakat: pertama menyempurnakan kemerdekaan bagi setiap induvidu 
masyarakatdalam hal ini ada nash yang mewajibkan kemerdekaan budak belian dari penghamban antara sesama manusia, dan ini merupakan syariat pertama yang diketahui manusia dalam memerdekakan budak belian, dengan mewajibkan kaum muslim mengeluarkan sebagian hartanya tetap untuk keperluan tersebut sebagaimana terdapat dalam al-Quran taubah ayat 60. Kedua membangkitkan semangat pribadi manusia dan nilai-nilai kemanusiaannya dalam menyerahkan sesuatu yang bermanfaat bagi masyarakat, baik mental atau materiallnya atau menolak sesuatu yang buruk yang dikuatirkan akan terjadi. Cukuplah kemuliaan dalam kehidupan ini yang bisa mendorong motivasi untuk berbuat baik, tambaham kecintaan dan kebikan, yang karena dari jiwa yang terang dan fitrah yang tinggi nilainya. Ini akan mengangkat harkat dan martabat nilai kehiduapan manusia, inilah yang dikehendaki Allah dalam menciptakaan hidup dan kehidupan manusia, jamaaah mempunyai kewajiban untuk mempersiapkan kamampuankemampuan tersebut pada setiap pribadi anggotanya agar ia produktif danberkembang, bukanya dengan ditinggalkan begitu saja dilemahkan keyakinannya dan dipadamkan sumbernya. Ketiga menelihara akidah dan pendidikan yang dimaksudkan untuk mensucikan dasar-dasar fitrah manusia, dan terutama untuk menghubungkan manusia dengan Allah, memberikan pandangan kepada sesorang tentang hakikat tujuan hidupnya dan tentang kehidupan akhiranta yang pasti manusia akan kembali kepadanya, tidak bisa tidak, karena kepastiannya yang bersifat ajali ini dinyatakan dalam firman Allah dan dalam jalan Allah, diantara makna yang dimaksudkan kedalam ayat dan dalam jalan Allah adalah biaya untuk perang dan pertahanan, yakni mempersiapkan pasukan, pertahanan dan ijtihad dalam Islam sesungguhnya pada dasarnya adalah untuk mempertahankan akidah dan membela agamNya, bukan semata masalah ekonomi atau materi, bukan pula jihad untuk membela tanah air sambil memutuskan hubungan dengan Allah, tetapi jihad itu, bahkan sebelum segala sesuatu adalah jihad dalam membela agama Allah saja, terutama dalam memelihara menegakan dan memantapkan akhidah sertamemperpanjang kekuasanNya. (Qardawi, 2007)

Manajemen dan sistem pengelolaan dana zakat di Indonesia belum seluruhnya profesional dan memuaskan, juga tidak membuat hati rakyat percaya sepenuhnya. Golden age yang begitu indah itu belum pernah terwujud dan tercicipi oleh bangsa dan negeri ini. Jika pada zaman Rasulullah dan khulafaurrasyidin negara berperan aktif dengan model "jemput bola" dalam rangka mengumpulkan dan mendistribusikan zakat dari para muzakki kepada mustahiq, maka di Indonesia terjadi polarisasi. Pertama, para muzakkimenyerahkan zakatnya langsung pada pihak yang berhak menerima zakat (mustahiq). Kedua, zakat diserahkan kepada panitia atau badan/ lembaga amil zakat. bahwa di antara tujuan pengelolaan zakat adalah untuk mewujudkan kesejahteraan masyarakat dan menanggulangi kemiskinan. Sejauh ini, program penanggulangan kemiskinan kerap menghadapi kendala, antara lain, luasnya masalah kemiskinan, penanganan kemiskinan tidak integral dan ego sektoral kuat, tidak melibatkan dan memberdayakan (empowering) orang miskin, peraturan tidak memihak orang miskin, kemiskinandilihat sebagai masalah modal dan keterampilan sernata. Pada prosesnya, masyarakat diajak untuk mengenali beberapa persoalan yang menjadikan kemiskinan itu sebagai lingkaran hidup mereka yang tidak berkesudahan. Persoalan-persoalan yang perlu dikenali tersebut adalah a) psikologi kemiskinan atau keyakinan mental tidak mampu mengatasi dan

\author{
Muhammad \\ Ngasifudin \\ 228
}

JURNAL EKONOMI SYARIAH INDONESIA, Volume V, No.2 Desember 2015 
keluar dari hidup miskin, b) budaya kemiskinan atau sikap dan perilaku hidup miskin yang terwariskan dari generasi ke generasi, dan c) personalisasi kemiskinan atau keyakinan dan mindset individu yang tidak mampu mengubah kondisi dirinya. (Kementrian Agama Republik Indonesia, 2013)

Perintah mengambil zakat dari muzakki melalui amilin yaitu orang yang ditugaskan diutuskan oelh imam/ pemerintah untuk mengambil, menuliskan, menghitung dan mencatat zakat yang diambilnya dari pada muzakki untuk kemudiandiberikan kepada yang berhak menerimnaya, menunjukan kewajiban zakat itu bukanlah semata-semata bersifat amal karitatif sekedarmawanan, tetapi juga ia suatu kewajiban yang bersifat otoritatif, penunaian kewajiban zakat dan anjuran berinfaq dan bersedeqah adalah ajaran yang amat penting dalam islam untuk menata kesejahteraan masyarakat secara keseluruhan, Zakat infaq dan sedeqah yang dikelola dengan baik dan amanah oleh lembaga profesional adalah merupakan sumber dana bagi pembanguanan sarana maupun prasarana yang dibutuhkan umat islam, seperti sarama ibadah, pendidikan, kesehatan, sosial, dam ekonomi sekaligus sarana pengembangan kualitas sumberdaya manusia muslim, dalam melangkah kedepan ada beberapa hal yang perlu dilakukan oleh seluruh pengelola zakat dalam rangka pengalian dan pemanfaatan dana ZIS untuk kesejahteraan para mustahiq, Pertama Optimaslisasi sosialisasi zakat, perlu disadari bahwa zakat membutuhkan sosialisasi yang lebih mendalam, harus diakui bahwa pada satu sisi, kesadaran masyarakat untuk berzakat semakin meningkat dari waktu kewaktu, namun pada sisi lain, antara potensi dana zakat dan realisasinya pengumpulan terdapat gap yang sangat besar, koordinasi dankerjasama simpul-simpul masyarakat baik itu para ulama, ormas-ormas Islam, cendekiawan, maupun masyarakat awam, harus lebih diperkuat, kedua, membangun citra lembaga zakat yang amanah dan profesional, hal ini sangat penting untuk dilakukan mengingat saat ini telah menjadi krisis kepercayaan antar sesama komponen masyarakat. Akuntabilitas, transparasi dan corporate culture merupakan tiga hal pokok yang menentukan citra lembaga yang amanah yang profesional, harus disadari bahwa profesi amil ini bukan merupakan sampingan yang dikerjaakan dengan tenaga dan waktu sisa, ini membutuhkan komitmen dan kesungguhan dalam prakteknya, ketiga, adalah membangun sumber daya manusia yang siap untuk berjuang dan mengembangkan zakat di Indoensia, keempat, memperbaiki dan menyempurnakan perangkat peraturan zakat di Indonesia. Kelima memangun data base mustahiq zakat dan muzakki secara nasional, sehinggi diketahui peta persebarannya secara tepat. Indikator seorang apakah terkatagorikan sebagai mustahiq ataupun menjadi muzakki juga harus di atur jelas, tepat, dan disesuaikan dengan kondisi yang ada. Keenam menciptakan standarisasi mekanisme BAZ dan LAZ sebagai parameter kinerja kedua lembaga tersebut, sellama ini belum ada standar baku dalam prakteknya, untuk itu hal itu telah menjadi kebutuhan yang sangat mendesak agar masyarakat memiliki ukuran yang jelas di dalam megontrol pengelolaan zakat ditanah air, standarisasi tersebut juga dimaksudkan sebagai indikator transiparasi dan akuntabilitas institusi zakat. Ketujuh, memperkuat sinergi atau ta' awun antar lembaga zakat, Kedelapan membangun sistem zakat nasional yang mandiri dan profesional,

Konsep Sistem ini adalah ultimate goal yang harus menjadi target kita bersama sistem yang diharapakan adalah sistem yang dibangun atas delapan landasan. (Ghufran, 2008) 


\section{KESIMPULAN}

Permasalah yang mendasar dari umat Islam khusunya indonesia dewasa ini adanya kenyataan kontradiktif antara jumlah umat yang kondisi ekonominnya berkecukupan dan masyarakat yang kondisi ekonominya kekurangan, perjalanan penglolaan zakat di Insonesia memiliki sejarah panjang, Karena itulah, sejarah hidup manusia juga tidak lepas dari sejarah bagaimana mana manusia mengelola zakat untuk berbagai kepentingan, termasuk untuk menghapus kemiskinan.

Zakat adalah kewajiban setiap induvidu muslim dan menjadi ukuran kedermawanaan seseorang kepada hamba Allah, SWT, jika kita untuk zakat saja kita merasa berat untuk mengeluarkan, bagaimana pula dengan infak dan sedeqah yang hukumnya hanya sunat. Zakat adalah langkah kemandirian sosial yang diambil dengan dukungan penuh agama untuk membantu orangorang miskin dan fakir yang tidak mampu memenuhi kebutuhan mereka sendiri dan untukk menghapus kesenjangan dan kesengsaraan, kemiskinan masyarakat muslim, Islam mengajarkan kepada pemeluknya untuk selalu berbuat kebaikan sesama umat bukan saja hanya dalam makna ibadah mahdah (hubungan vertikal) tetapi dengan makna bagaiman menciptakan tatanan sosial (hubungan horisontal), Penyadaran masyarakat ini untuk mengeluarkan zakat ini sangat penting karena zakat merupakan pilar Islam yang memilki nilai sosial dan baik pemberi zakat mapun penerima zakat.

\section{DAFTAR PUSTAKA}

al-Qardawy, Syekh Muhammad Yusuf. 1999, Konsemsi Islam dalam Mengentas Kemiskinan, Terj. Umar Fanany, Surabaya: PT. Bina Ilmu,

al-Qardawy, Syekh Muhammad Yusuf. 2007, Fiqhuz-Zakat, Terj. Dr. Salman harun, Drs Didin Hafidhuddin, Drs. Hasanudin , Surabaya: Litera AntaNusa

Kementrian Agama Republik Indonesia, 2011, Petunjuk pelaksanaan Kemitraan dalam pengelolaan Zakat, Jakarta.

Ma'arif, A. Syafi'i dkk. 2007, Islam, Good Governance, dan Pengentasan Kemiskinan, Kebijakan Pemerintah, Kiprah Kelompok Islam, dan Potret Gerakan Inisiatif Di Tingkat Lokal. Jakarta: MAARIF Institute for Culture and Humanity.

Majalah Badan Amil Zakat Nasional (BAZNAS), 2015, "Menguatkan Peran zakat dalam Pembangunan daerah"Edisi Mei-Juni, Jakarta, hlm 8-9

Mas'udi, Masdar F., 1991, Agama Keadilan (Risalah Zakat (pajak) Dalam Islam), Jakarta : Pustaka Firdaus.

Lapidus, Ira. M, 2000, Sejarah Sosial Ummat Islam, terj. Ghufron A. as'adi Jakarta: RajaGrafindo Persada.

Kementrian Agama Republik Indonesia, 2013, Modul penyuluhan Zakat, Jakarta.

Nasution, Mustafa Edwin, 2006, Pengenalan Eksklusif Ekonomi Islam, Jakarta: Kencana.

Kementrian Agama Republik Indonesia, 2013, Standarisasi Amil Zakat Indonesia, Jakarta.

Muhammad

Ngasifudin

JURNAL EKONOMI SYARIAH INDONESIA, Volume V, No.2 Desember 2015 
Permono, Sjechul Hadi, 1995, Pemerintah Republik Indonesia Sebagai Pengelola Zakat Jakarta: Pustaka Firdaus, hlm. 131

Qodir, Abdurrachman, 1998, Zakat dalam Dimensi Mahdhah Dan Sosial, Jakarta: Raja Grafindo Persada

Azra, Azyumardi, 2006, "Filantropi dalam Sejarah Islam diIndonesia" dalam Kuntarno Noor Aflah (editor), Zakat \& Peran Negara,(Jakarta: Forum Zakat (FOZ),

Daud Ali, Muhammad, 1988, Sistem Ekonomi Islam Zakat dan Wakaf Jakarta: UI Press.

Fakhruddin, 2008, Figh dan Manajemen Zakat di Indonesia, Malang: UINMalang Press,

Rahardjo, Dawam, 1987, Perspektif Deklarasi Makkah Menuju Ekonomi Islam, Bandung: Mizan.

Gufran dkk, 2008, Membangun kembali Peradaban Zakat, Yogyakarta: Unggun Religi 